\title{
Aquatic Oligochaete Communities in Amazonian Streams, Saracá-Taquera National Forest, Pará, Brazil
}

\author{
Maria Silvina Bevilacqua ${ }^{1 *}$, Mercedes Rosa Marchese ${ }^{2}$, Rodrigo Weber Felix ${ }^{l}$, João José Fonseca Leal ${ }^{3}$, \\ Marcos Paulo Figueiredo de Barros ${ }^{1}$, Reinaldo Luiz Bozelli ${ }^{4}$ \& Francisco de Assis Esteves ${ }^{1,4}$ \\ ${ }^{1}$ Universidade Federal do Rio de Janeiro, Laboratório de Ecologia Aquática, Núcleo em Ecologia e \\ Desenvolvimento Ambiental de Macaé, Macaé, RJ, Brasil \\ ${ }^{2}$ Instituto Nacional de Limnologia, Ciudad Universitaria - Paraje El Pozo, CP 3000, Santa Fe, Argentina \\ ${ }^{3}$ Instituto Federal de Educação, Ciência e Tecnologia, Centro, Nilópolis, RJ, Brasil \\ ${ }^{4}$ Universidade Federal do Rio de Janeiro, Departamentos de Ecologia, Av. Carlos Chagas Filho, 373, \\ Ilha do Fundão, Cidade Universitária, Rio de Janeiro, RJ, Brasil \\ *Corresponding author: Maria Silvina Bevilacqua, e-mail: mariasilvinabevilacqua@gmail.com
}

BEVILACQUA, M.S., MARCHESE, M.R., FELIX, R.W., LEAL, J.J.F., BARROS, M.P.F., BOZELLI, R.L., ESTEVES F.A. Aquatic Oligochaete Communities in Amazonian Streams, Saracá-Taquera National Forest, Pará, Brazil. Biota Neotropica. 20(1): e20180654. http://dx.doi.org/10.1590/1676-0611-BN-2018-0654

\begin{abstract}
The aim of this study was to analyze aquatic oligochaete distribution in relation to water column physicochemical variables, structural environmental variation, and predominant substrates in the preserved Amazonian streams of the Saracá-Taquera National Forest (FLONA Saracá-Taquera), northwest Pará, Brazil. Oligochaetes are widely used as bioindicators for monitoring aquatic environments as they are very sensitive to pollution and environmental changes. Physicochemical and structural variables were measured from 100 stream segments in order to understand the distribution of oligochaetes in Amazonian streams. Biotic samples were collected using Surber samplers in three of the most predominant substrate types in each segment. PERMANOVA testing showed that there was a significant difference in the oligochaete community among some substrates, potentially caused by a difference in the abundance of the most common taxa. Canonical Correspondence Analysis showed that physical variables drive the distribution of oligochaetes in preserved Amazonian streams, as they determine the formation of different substrates along the stream, from the source to the mouth; favoring the presence of oligochaetes with more specific ecological needs in low-order streams, and the presence of oligochaetes capable of colonizing various types of substrates and deeper zones in high-order streams. These results suggest that water depth and channel width are the main drivers of aquatic oligochaete distribution along Amazonian streams, determining the formation of unstable and low-quality substrates and, consequently, the low colonization by oligochaetes in high-order streams; and more diverse and stable substrate formation in low-order streams, favoring the colonization by diverse taxa of aquatic oligochaetes in low-order Amazonian streams.
\end{abstract}

Keywords: Aquatic macroinvertebrates, biomonitoring, tropical streams, substrates, stream hydrology, mining activities.

\section{Comunidade de oligoquetos aquáticos em riachos amazônicos, Floresta Nacional Saracá-Taquera, Pará, Brasil}

Resumo: O objetivo deste trabalho foi analisar a distribuição da comunidade de oligoquetos em relação às variáveis físico-químicas da coluna da água, variação estrutural do ambiente, e substratos predominantes em riachos amazônicos conservados na FLONA Saracá-Taquera, noroeste do Pará, Brasil. Oligochaetes são amplamente utilizados como bioindicadores para monitoramento de ambientes aquáticos, pois são muito sensíveis à poluição $\mathrm{e}$ às mudanças ambientais. Variáveis físico-químicas e estruturais de 100 trechos de riachos foram mensuradas para entender a distribuição de oligoquetos em riachos amazônicos. Amostras bióticas foram coletadas com amostrador Surber em três dos tipos de substratos mais predominantes em cada trecho. A PERMANOVA mostrou que há uma diferença significativa da comunidade de oligoquetos entre alguns substratos, possivelmente baseada nas diferenças no número do táxon mais comum. AAnálise de Correspondência Canônica mostrou que as variáveis físicas controlam a distribuição da comunidade de oligoquetos em riachos amazônicos preservados, porque estas variáveis determinam a formação dos diferentes substratos ao longo do riacho, desde a nascente até a foz, favorecendo a presença de 
oligoquetos com necessidades ecológicas mais específicas em riachos de baixa ordem, e oligoquetos capazes de colonizar diferentes tipos de substrato e zonas mais profundas em riachos de ordem maior. Os resultados deste trabalho sugerem que a profundidade da água e a largura do canal são as variáveis que controlam a distribuição da comunidade de oligoquetos em riachos amazônicos, determinando a formação de substratos instáveis e de baixa qualidade, e consequentemente baixa colonização de oligoquetos, em riachos de ordem maior; e formação de substratos mais diversificados, mais estáveis e de qualidade em riachos de baixa ordem, favorecendo a colonização de diversos taxa de oligoquetos aquáticos em riachos amazônicos de baixa ordem.

Palavras-chave: Macroinvertebrados aquáticos, biomonitoramento, riachos tropicais, substratos, hidrologia de riachos, atividades de mineração.

\section{Introduction}

Oligochaetes play important roles in aquatic systems, such as in food webs, as a source of food for other invertebrates, fish, and birds (Ezcurra de Drago et al, 2007); in the organic matter decomposition process; and also fulfilling an important role in the cycling of nutrients, participating in sediment structuring and nutrient exchange in the water/ sediment phase (Golterman et al., 1983).

They are good indicators of environmental conditions (Verdonschot, 2001) because they have limited mobility, long life cycles, an intimate relationship with substrates and they are extremely influenced by the habitat characteristics in which they live (Behrend et al., 2009). Different species of oligochaetes are sensitive, moderately tolerant or highly tolerant to physicochemical changes in aquatic ecosystems (Yap et al., 2006, Rodrigues and Reynoldson, 2011, Burdon, et al., 2019). Although many studies evaluate the macroinvertebrate community in tropical streams, oligochaetes are often ignored or identified only as a subclass or family, downplaying the group's role as a bioindicator (Lopes et al., 2011; Couceiro et al., 2009; Alves et al., 2008; Fidelis, 2006; Walker, 2004).

Studies have demonstrated that Oligochaeta species have a wide range of responses to contamination by nutrients, metals, and organic chemicals, showing distribution patterns which are associated with pollution and contaminants (Rodriguez and Reynoldson, 2011). However, there is limited literature about how this group responds to physical factors, such as fine sediment inputs, deforestation and mining activities in lotic environments. Therefore, it is important to know how oligochaetes are distributed and which of this community's structuring variables are present in tropical systems like those found in the Amazon, whereby mineral exploitation is an expanding activity that can impact these environments (Castello and Macedo, 2016).

According to some studies on streams, the main factors that influence aquatic oligochaetes composition and distribution are water flow, waterbody width and depth, and substrate characteristics (Nijboer, 2004, Rosa et al. 2015). However, other factors seem to play a role in shaping oligochaete communities depending on context. Syrovátka (2009) suggested that flow velocity and habitat preference explain the spatial pattern of oligochaete distribution in a small highland stream. Blettler (2008) found a marked relationship between the different substrate types and the oligochaetes associated with them and, according to this author, some physical factors such as water velocity and depth may influence the establishment and availability of the substrates, as well as the composition of their associated fauna. However, other authors such as Prenda and Gallardo (1992) and Schenkova and Helesic (2006) affirm that oligochaetes do not have habitat preferences and show a broad ecological tolerance. More information from tropical streams is needed in order to draw a big picture about the importance of environmental variables in oligochaete distribution.

Central Amazonian streams are low-order heterotrophic environments (Junk, 1983; Lima and Gascon, 1999), and the forest next to the streams supplies them with resources and material to form different kinds of aquatic fauna substrates. The dependence on allochthonous organic matter produces a link between the characteristics of the forest that surrounds the streams and the composition of local aquatic fauna, including some fish and most benthic invertebrates, which is associated with the meso- and micro-habitats structured within them (Nessimian et al., 1998). Thereby faced with different impacts near these kinds of environment the stream bottom can suffer physicochemical and structural transformations, leading to the modification of substrates and their associated fauna (Dedideu et al., 2015). Low-order Amazonian streams are homogeneous in relation to water column physicochemical variables. They are clear, acidic, have low conductivity, constant temperatures and low alkalinity waters, and they are not influenced by the flood pulse of big rivers. Therefore, their periodic flow change is influenced by local daily rainfall, with noticeable changes during different seasons (Junk, 1983). All this information suggests that water column physicochemical factors do not influence $t$ oligochaete community distribution in preserved Amazonian streams; rather, it may be structural and physical factors which influence this distribution.

Considering the homogeneity of the water column physicochemical variables of the Amazonian streams, we hypothesize that oligochaetes distribution in Amazonian streams is determined by physical and structural variables like the flow, depth and substrate material at the bottom of the streams. Therefore, this study aims to analyze oligochaetes distribution in relation to the physicochemical variables of the water column; physical variation; and predominant substrates in preserved Amazonian streams in Brazil. This is a piece of valuable knowledge for the development of biomonitoring tools to assess Amazonian streams; as well as contributing to the body of knowledge about these invertebrates in the region, which is still fragmented and incomplete in all Brazilian freshwater systems (Takeda et al., 2017).

\section{Material and Methods}

\section{Study area}

The study was carried out in the Saracá-Taquera FLONA, in the northwest of the state of Pará (Brazil) (Figure 1). It is located on the right bank of the Trombetas River, between the municipalities of Terra Santa, Oriximiná, and Faro, near the political division of the state of Amazonas. 
The FLONA is responsible for the protection of 441,282.63 hectares of the Amazon Biome (Ministério do Meio Ambiente, 2001). The region is covered by tropical rainforest, with annual rainfall rates ranging between 1,900 and 2,500 $\mathrm{mm}$ and a dry season from June to October with less than $100 \mathrm{~mm}$ of monthly rainfall (Sioli, 1985). Authorized bauxite extraction occurs within the Saracá-Taquera FLONA, and the streams in this region are impacted in different ways by the products of this activity (such as deforestation, siltation, damming, suppression of riparian forest, etc.), leading to the eventual or permanent modification of the characteristics of these environments.

The entire region is drained by small streams, composed of acidic ( $\mathrm{pH} 4.5-5.4)$ and low turbidity (clear) waters with low conductivity (7.9-16.7 $\mu \mathrm{S} . \mathrm{cm}^{-1}$ ) and average temperatures of $24^{\circ} \mathrm{C}$ (Mortatti, 2004). These streams do not suffer from significant seasonal variations of physicochemical variables, which is indicative of their great environmental stability instead, local rainfall is responsible for variation of these parameters (Nessimian et.al. 2008).

In the Amazon region low-order streams (1st to 3rd order) have, under natural conditions, a full canopy cover that shades them entirely, reducing the primary productivity within them. Larger streams (4th and 5th orders) have lower coverage of surrounding forest, increasing the incidence of light in the stream and favoring the growth of aquatic macrophytes within the channel.

Furthermore, the streams exhibit different channel geomorphologies. Larger streams have well-structured margins, supported by tree roots and riparian vegetation, and the smaller ones generally do not present defined margins. Generally, the bed of the stream is sandy with plant litter accumulation consisting of leaves and wooden materials from surrounding forest in some spots. Branches and trunks act as retention mechanisms in the streams, generating small rapids and pools, favoring the formation of deposition and retention areas which increase environmental heterogeneity (Fidelis, 2006).

\section{Abiotic characterization of the streams}

Overall, 100 stream segment samples from 1 st to 5 th order, were collected in the months of March (rainy season) and September (dry season), from 2009 to 2011. In each site, the water temperature (electronic thermometer, 0.1 of accuracy), dissolved oxygen in water (YSI Portable Mod. 550A), water depth, channel width, and the substrate types were measured. To evaluate substrate characteristics, a 50 by 50 $\mathrm{cm}$ quadrat was used, subdivided into 25 smaller squares. This method consisted of a visual estimate of the percentage of squares filled by the different types of substrate (USEPA, 2004). Water depth was measured with a ruler on two transverse transects in the sampling point, with ten depth measurements being taken from each transect, and the average depth was calculated. Channel width was measured on the same transverse transects as depth, and the average width was calculated. In addition, $1 \mathrm{~L}$ of water was collected in polyethylene bottles at each point and taken to the laboratory for $\mathrm{pH}$ analysis (QUIMIS-Mod. Q400MT benchtop), electrical conductivity measuring (QUIMIS benchtop electronic conductivity meter), and turbidity analysis (Del Lab DL350 portable microprocessor turbidimeter).

\section{Biotic sampling and identification}

In each sampled segment three of the most predominant substrate types were collected, and these were grouped in six categories in accordance with their composition: sand and leaves (SAN+LEA), sand only (SAN), sand with fine organic matter (SAN+MO), macrophytes (MC), gravel (GRA) and roots (ROO). The samples were collected using a "Surber" sampler with an area of $0.09 \mathrm{~m}^{2}$ and a $250 \mu \mathrm{m}$ mesh

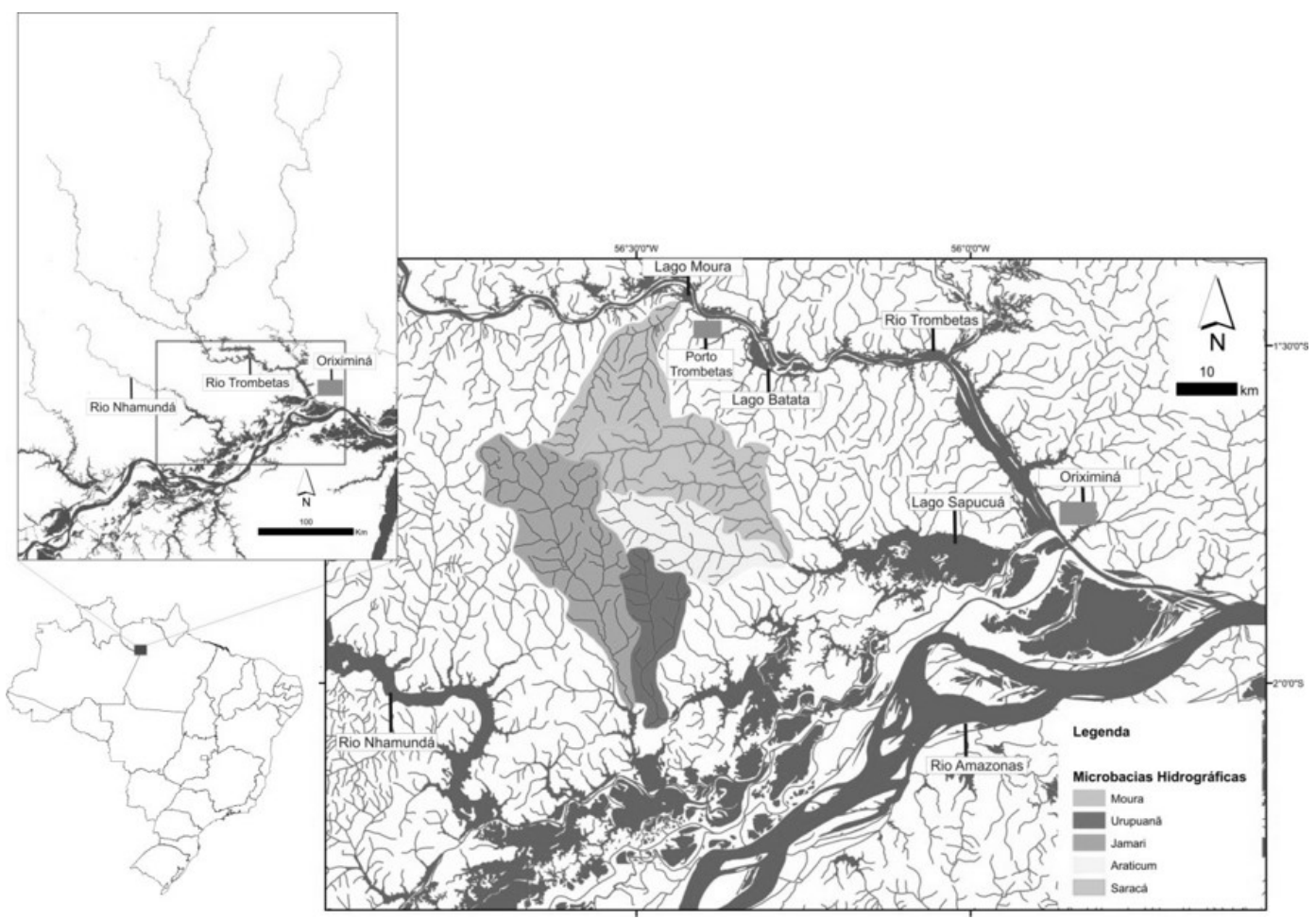

Figure 1. Study Area. Saracá-Taquera National Forest, Municipality of Oriximiná, Pará, Brazil. The micro-basins painted in shades of lighter gray are part of the Trombetas River basin, and the darker grays are part of the Nhamundã River basin. 
opening. The samples were stored in plastic bags and transported to the laboratory, where they were washed in a sieve with a $0.5 \mathrm{~mm}$ mesh. Subsequently, the organisms were separated and preserved in $70 \%$ alcohol for the identification of the lowest possible taxonomic levels (dependent on the taxonomic characteristics required to obtain family, genus and species levels) under an optical microscope with the help of different identification keys (Brinkhurst and Marchese, 1989; Pinder, 2010; Brinkhurst \& Jamieson, 1971).

\section{Data analysis}

Canonical Correspondence Analysis (CCA) was used to explore which variables better explain oligochaete distribution along the streams. A PERMANOVA test was used to evaluate whether there was a significant difference in oligochaete assemblage per substrate, and a SIMPER test was performed in order to identify which taxa most contributed to the differences among the substrates. All analyses were performed using PAST statistical software v3.14.

\section{Results}

Sampled streams were similar in physicochemical characteristics: transparent and oxygenated waters $[2,02( \pm 2,70)$ NTU; $5,92( \pm 1,12)$ $\left.\mathrm{mg} \mathrm{L} \mathrm{L}^{-1}\right]$, mean water temperatures of $25^{\circ} \mathrm{C}( \pm 0,65)$, an acidic $\mathrm{pH}$ $[4,9( \pm 0,18)]$ and low conductivity $[11,06( \pm 4,46) \mu \mathrm{S} / \mathrm{cm}]$ (Table 1$)$. Moreover, these streams do not have significant water nutrient charges due to the soil characteristics found in the Trombetas river watershed (Sioli, 1989).

A total of 780 aquatic oligochaetes were identified in 10 taxa, represented by six families: Naididae, Enchytraeidae, Haplotaxidae, Lumbriculidae, Alluroididae, and Glossoscolecidae. The oligochaetes composition in each substrate can be found in Table 2 .

Most taxa were associated with higher organic matter loading substrates. All identified taxa occurred in the SAN+LEA substrate, and Bratislavia unidentata (Harman, 1978) and Aulodrilus pigueti (Kowalewski, 1914) were found exclusively in this substrate. The taxa Glossoscolecidae n.i, Haplotaxis sp. (Hoffmeister, 1843), Tubificinae n.i1 and Lumbriculidae n.i., were recorded in greater abundance in the SAN+LEA substrate. Nais communis (Piguet, 1906) was also present in substrates with higher organic matter loading, such as SAN+LEA and $\mathrm{SAN}+\mathrm{OM}$, as well as substrates with lower organic matter loading, such as GRA. Brinkhurstia americana (Brinkhurst, 1964) occurred in all substrates except for GRA, and showed the highest abundance in SAN + LEA and SAN + OM substrates. The Enchytraeidae family occurred in all sampled substrates, but showed higher abundance in the ROO substrate and the second highest abundance in the MC substrate (Figure 2).
The CCA revealed that the first axis explained $72 \%$ of data variability (statistical significance by randomization test $p=0,001$ ) (Figure 3). The first axis was described by the substrate variable to the right of the graph, and by the water depth and channel width to the left. Streams from 1st to 3rd order were distributed to the right of the graph and 4th and 5th orders were distributed to the left of the graph. Oligochaetes taxa were associated with the substrate, water depth, and channel width, which are related to the order of the stream. Tubificinae n.i2, Lumbriculidae, Glososcolecidae, Nais communis (Piguet, 1906) were linked to substrate variables in low-order streams (1st to 3 rd order); and Brinkurstia americana (Brinkhurst, 1964), Aulodrilus pigueti (Kowalewski, 1914), Tubificinae n.il and Enchytraeidae n.i were associated with wider and deeper streams.

\section{Statistical analysis}

PERMANOVA(Table 3) showed that there is a significant difference between Oligochaeta communities registered in ROO and in the substrates SAN, SAN+LEA, and GRA, with no significant difference between the communities registered in the ROO, SAN+OM, and MAC substrates. The SIMPER test showed that the taxa which contributed the most to this difference were Enchytraeidae (26.81\%), Brinkhurstia americana (Brinkhurst, 1964) (23.3\%), and Tubificinae n.i1 (19.63\%).

\section{Discussion}

As expected, this study showed that substrate types, water depth, and channel width are the main drivers of aquatic oligochaetes distribution in Amazonian streams. These variables determine the formation of unstable substrates in high order streams; substrates that cannot be used as refugia and lacking in food sources, which may limit the colonization and establishment of some Oligochaeta species. On the other hand, these physical variables influence the formation of stable substrates in loworder streams, which are good as refugia and can possibly offer enough food sources to create specific microhabitats that enable colonization by more specific oligochaetes taxa.

Our results showed that Oligochaeta species abundance can be partially explained by the type of substrate associated with the order of the streams. The ROO substrate showed significant differences in oligochaete community patterns compared to other substrates, and the taxa that most contributed to this difference were Enchytraeidae, $B$. americana (Brinkhurst, 1964) and Tubificinae nil. Since these taxa occur in all substrates, the significant difference among the substrates could be related to the abundance levels of such taxa in each substrate. All taxa identified at the present study occurs in the substrates indicated by the bibliography and some aquatic oligochaetes taxa occur in low abundance in specific substrates [N. communis (Piguet, 1906), B.

Table 1. Abiotic parameters measured with the mean, standard deviation, minimum value and maximum value; $\mathrm{pH}$, Water conductivity (CON); Turbidity (TUR); Water temperature (TEM), Dissolved Oxygen (O2); Channel Depth (PR), Channel Width (LC).

\begin{tabular}{|c|c|c|c|c|c|c|c|}
\hline & $\begin{array}{c}\text { Channel } \\
\text { width }(\mathrm{m})\end{array}$ & $\begin{array}{c}\text { Channel } \\
\text { depth (m) }\end{array}$ & $\begin{array}{c}\text { Water } \\
\text { Temperature }\left({ }^{\circ} \mathbf{C}\right)\end{array}$ & pH & $\begin{array}{l}\text { Water conductivity } \\
(\mu \mathrm{S} / \mathrm{cm})\end{array}$ & $\begin{array}{l}\text { Turbidity } \\
\text { (NTU) }\end{array}$ & $\begin{array}{c}\text { Dissolved } \\
\text { oxygen }(\mathrm{mg} / \mathrm{L})\end{array}$ \\
\hline Mean & 3,57 & 0,54 & 25,78 & 4,90 & 11,06 & 2,02 & 5,92 \\
\hline Minimum value & 0,2 & 0,05 & 23 & 4,58 & 6,54 & 0,1 & 0,23 \\
\hline Maximum value & 25,5 & 3,1 & 29,2 & 5,72 & 38,1 & 13,2 & 17,5 \\
\hline
\end{tabular}


Table 2. List of aquatic oligochaetes taxa identified in each sampled substrate. Substrates: Sand (SAN), Sand + Leaves (SAN+LEA), Gravel (GRA), Macrophytes $(\mathrm{MAC})$, Sand + Organic Matter (SAN+OM), and Roots (ROO). The symbol $(+)$ represents the presence and $(-)$ represents the absence of the taxa in each sampled substrate.

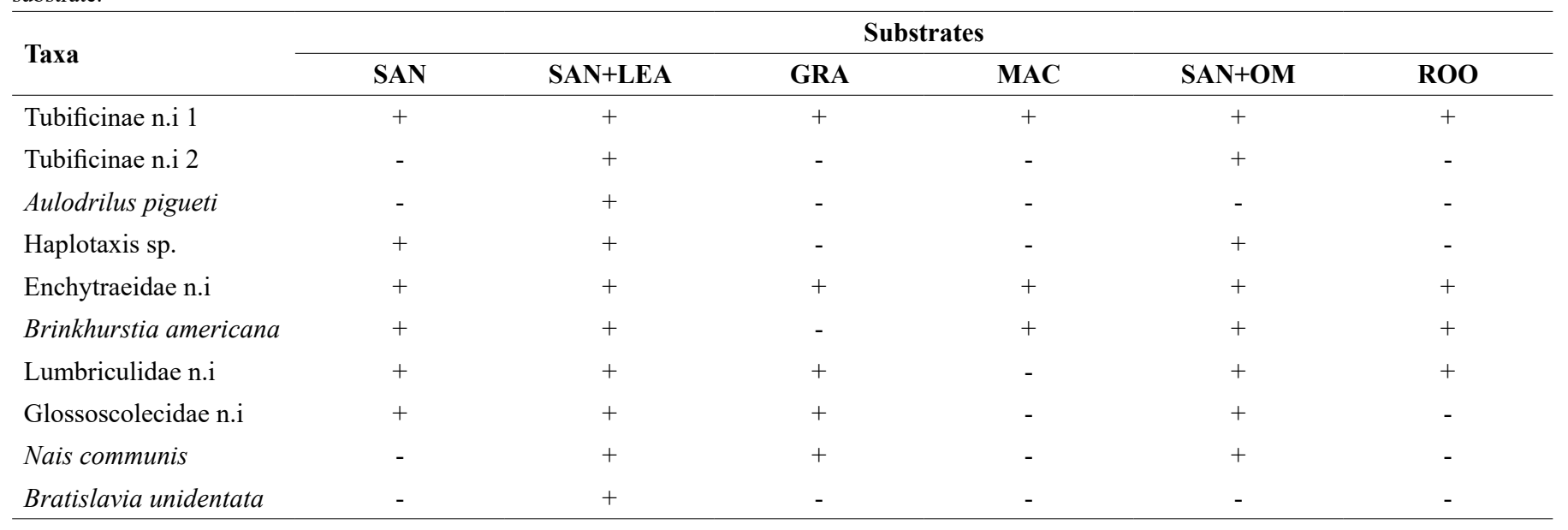

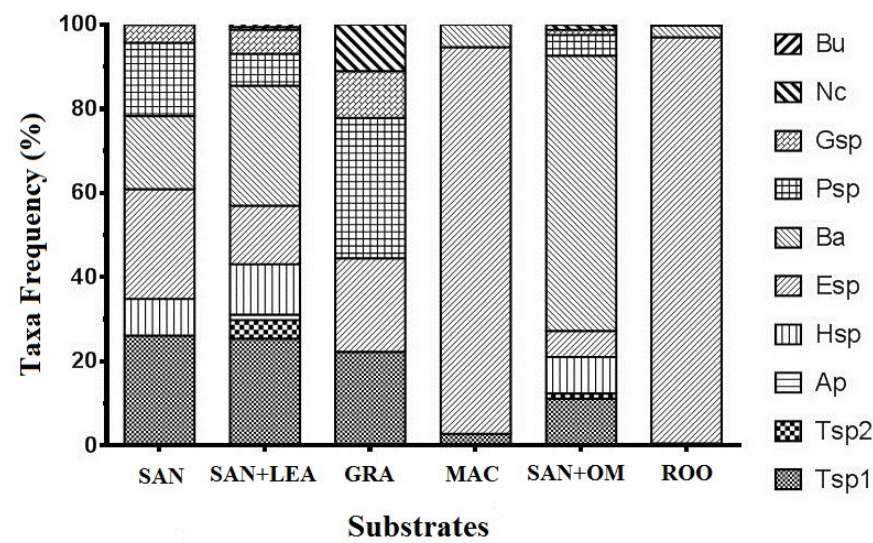

Figure 2. Relationship between the sampled substrates and the occurrence frequency of aquatic oligochaetes. Substrates: Sand (SAN), Sand + Leaves (SAN + LEA), Gravel (GRA), Macrophytes (MAC), Sand + Organic Matter (SAN + $\mathrm{OM}$ ), and Roots (ROO). Bu - Bratislavia unidentata; $\mathrm{Nc}$ - Nais communis; Gsp - Glossoscolecidae ni1; Psp - Lumbriculidae ni1; Ba - Brinkhurstia americana; Esp - Enchytraeidae ni1; Hsp - Haplotaxis ni1; Ap - Aulodrilus pigueti; Tsp1 - Tubificinae ni1; Tsp2 - Tubificinae ni2.

unidentata (Harman,1978), and A. pigueti (Kowalewski, 1914)], which could be understood as a habitat preference when the substrates are available; whereas other taxa seem to have greater plasticity to colonize all types of substrate that could be formed in low- to high-order streams.

In the present study, the SAN+LEA substrate showed the highest richness and diversity of aquatic oligochaetes. This substrate provides food and shelter for different macroinvertebrates and fish species (Passos et al., 2003). A. pigueti (Kowalewski, 1914) and the two morphospecies of the Tubificinae subfamily were recorded as having higher abundance in this substrate, which corroborates with what was observed by Alves and Strixino (2000) and Behrend (2009), that where these groups occur is also associated with an abundance in organic matter. Those taxa are abundant in this kind of substrate because, generally, they ingest sediment particles, digesting bacteria and fungi present in them, which accelerates the decomposition of organic matter (Wavre and Brinkhurst, 1971).
The Tubificinae subfamily is characterized by a high abundance in polluted areas and high tolerance to organic pollution caused by the presence of domestic wastewater in aquatic environments (Martins et al., 2008). The present study registered a considerable abundance of tubificids; therefore, the occurrence of this taxon must be carefully analyzed, since the high abundance of this group in preserved Amazonian streams is a natural condition and does not necessarily indicate environmental pollution. As specified by Rodriguez \& Reynoldson (2011), not all species respond in the same way to all types of pollutants and impacts, and it is necessary to identify the occurring species in order to stipulate their contaminating or impacting agents, and to analyze their effects on oligochaetes communities through specific studies. The subfamily level identification may lead to misinterpretation of the environmental integrity of the studied streams. A useful tool to assess environmental health conditions would be to identify the individuals of this group at the lowest taxonomic levels in order to understand the different tolerance to pollution of each species. However, in this study, many individuals of Naididae family could not be identified to species level because they were not sexually mature, which could be explained by the fact that the asexual reproduction of Naididae is generally employed during favorable environmental conditions, and sexual reproduction predominates in stressful conditions (Parish, 1981). This could indicate that the abundance of non-reproductive individuals of Tubificinae subfamily could be an important metric to assess the environmental integrity of Amazonian streams.

The genus Haplotaxis (Hoffmeister, 1843), deemed predatory because of its well-developed muscular pharynx (Brinkhurst \& McKey-Fender 1991), had an abundant presence in the SAN+LEA substrate. The wide variety of benthic invertebrates and availability of food sources that the substrate SAN+LEA provides (Rezende, 2007) could justify the higher abundance of Haplotaxis (Hoffmeister, 1843) in this substrate.

In this study, $N$. communis (Piguet, 1906) was registered in the SAN+OM, SAN+LEA, and GRA substrates. According to Dumnicka (1994), these substrates offer protection against predators. He also observed a relationship between $N$. communis (Piguet, 1906) and 
Bevilacqua, M.S. et al.

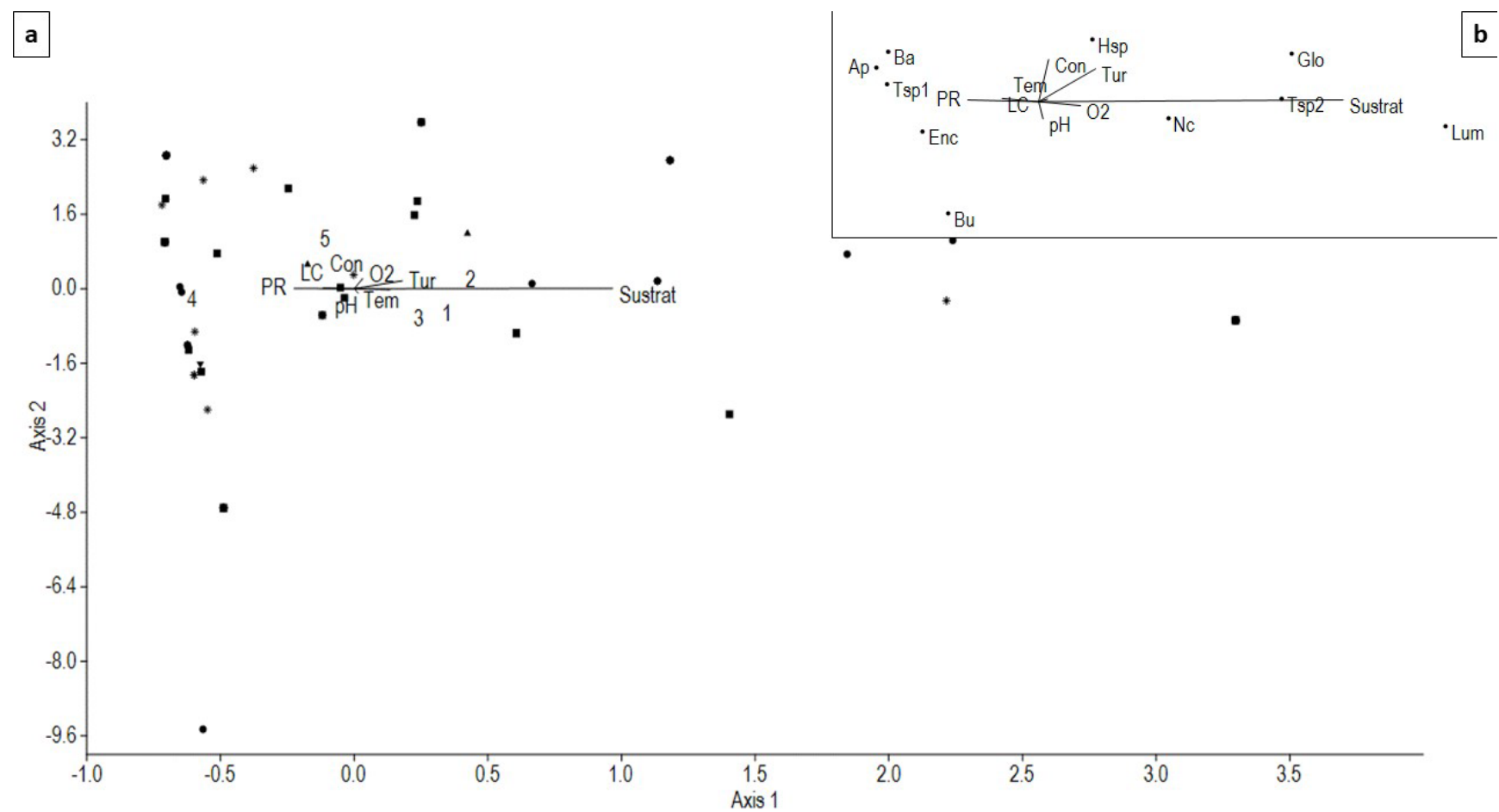

Figure 3. Canonical Correspondence Analysis. To facilitate visualization, the graph was split into two parts. Part "a" shows the streams around abiotic and structural variables. The numbers $1,2,3,45$, represent the stream order and how these groups are scattered on the graph. The symbols represent: $(\bullet) 1$ st stream order, $\left(^{*}\right)$ 2nd stream order, ( $)$ 3rd stream order, $(\boldsymbol{\Lambda})$ 4th stream order, and ( $\left.\mathbf{\nabla}\right)$ 5th stream order. Part "b" plots the relationship between abiotic and structural variables in accordance with the different taxa of Oligochaeta.

Table 3. One-way PERMANOVA testing of substrates and the aquatic oligochaetes found in each of them. Substrates: Sand (SAN), Sand + Leaves (SAN + LEA), Gravel (GRA), Macrophytes (MAC), Sand + Organic Matter (SAN + OM), and Roots (ROO). (*) indicates a significant difference (p $<0.05)$.

\begin{tabular}{lccccc}
\hline & SAN & SAN+LEA & GRA & MAC & SAN+OM \\
\hline SAN+LEA & 0.5354 & & & & \\
GRA & 0.4785 & 0.2346 & & & \\
MAC & 0.6873 & 0.7174 & 0.3489 & & \\
SAN+OM & 0.9022 & 0.9915 & 0.3948 & 0.7465 & \\
ROO & $\mathbf{0 . 0 4 5 *}$ & $0.0147^{*}$ & $0.0185^{*}$ & 0.5491 & 0.096 \\
\hline
\end{tabular}

rocky substrates covered with mud in the rapids of low-order streams. Also, according to Verdonschot (1999) N. communis (Piguet, 1906) is generally associated with substrates composed of fine sand and organic sediments, which justifies the occurrence of this species in the SAN+OM substrate. The occurrence of this species in gravel can be justified by the fact that the surface of the gravel would favor the growth of periphytic algae, one of the main food sources of $N$. communis (Piguet, 1906) and a determinant factor in Naidinae distribution.

The Enchytraeidae family was found in all substrates and had its highest abundance in ROO found in first-order, shallow, clear-water pristine streams with moderate concentrations of dissolved oxygen. Such characteristics resemble those described by Rodrigues et al. (2013) for streams in the state of Minas Gerais; and also, data from low-order streams in the state of São Paulo presented by Alves et al. (2008), with very different characteristics to Amazonian streams (low temperature $\left[16^{\circ} \mathrm{C}\right]$, neutral to alkaline $\mathrm{pH}[7$ to 8.5$]$ and water conductivity of 172.6 $\left.\mu \mathrm{S} . \mathrm{cm}^{-1}\right)$. This underscores the ability of this family to occur in a wide range of environmental conditions, allowing it to colonize a variety of environments: terrestrial, semi-aquatic, and aquatic, with different abiotic characteristics as well as various types of substrate.

The species B. americana (Brinkhurst, 1964) was registered in all substrates except gravel. This shows the ecological plasticity of this species, which can colonize several substrates under different conditions. According to Marchese (2010), this species usually occurs in sandy sediments, both of low-order streams and larger rivers. Other authors like Omodeo and Coates (2001) also associate it with lentic environments with profundal zones loaded with organic matter.

Glossoscolecidae is a common terrestrial earthworm family which also has aquatic representatives. In this study, the family occurred frequently in different substrates and was extremely prevalent in loworder streams. The high occurrence of this group in SAN+MO and SAN+LEA substrates and the link of this group to low-order streams and the substrate variable could be explained by ecological earthworm needs. It is common to think that the occurrence of earthworms in low-order streams is an accident derived from adjacent terrestrial populations, since the streams are narrow and shallow, intensifying the interaction 
between water and land (Rodrigues, 2013), but earthworms could be found at terrestrial, semi-aquatic and aquatic habitats. Truly aquatic earthworm species can be found in decaying vegetation in marshes and stream banks, in the soils of flooded rice paddies and along river margins and stream banks (James \& Brown, 2006) associated with bryophytes (Rodrigues, 2013).

In summary, the results of this work showed that the FLONA Saracá-Taquera streams were homogeneous in relation to physicochemical water parameters. Physical and structural variables such as the substrate, water depth, and channel width, combined with the order of the streams, were the environmental attributes driving oligochaete community distribution in these pristine environments. The results of this work provide an important base for the development of biomonitoring tools for these kinds of environment. Understanding the occurrence and distribution of aquatic oligochaetes in the streams of the FLONA Saracá-Taquera, in which impacts are generally the result of changes in land use, structural modifications due to mineral exploitation and siltation, and not by organic contamination, can add substantial value to the development of tools to evaluate environmental impacts in this region.

\section{Acknowledgements}

The authors are grateful to Conselho Nacional de Desenvolvimento Cientíco e Tecnológico (CNPq) for the scientific doctorate fellowship to Maria Silvina Bevilacqua. Furthermore, the authors are grateful to Mineração Rio do Norte for logistical support and thank the students João Gabriel Nogueira, Enoque Ribeiro and Felipe Abreu for English revision. The authors also want to thanks to the NUPEM/UFRJ (Instituto de Biodiversidade e Sustentabilidade, Universidade Federal do Rio de Janeiro, Macaé, RJ) by the laboratory support, and to the Postgraduate Program, PPG-Ciencias Ambientais e Conservação.

\section{Author Contributions}

Maria Silvina Bevilacqua: Contribution to data analysis and interpretation; Contribution to manuscript preparation; Contribution to critical revision, adding intellectual content.

Mercedes Rosa Marchese: Contribution to data analysis and interpretation; Contribution to manuscript preparation; Contribution to critical revision, adding intellectual content.

Rodrigo Weber Felix: Contribution to data analysis and interpretation; Contribution to manuscript preparation; Contribution to critical revision, adding intellectual content.

João José Fonseca Leal: Contribution to data collection; Contribution to critical revision, adding intellectual content.

Marcos Paulo Figueiredo de Barros: Contribution to manuscript preparation.

Reinaldo Luiz Bozelli: Contribution to critical revision, adding intellectual content.

Francisco de Assis Esteves: Contribution to critical revision, adding intellectual content.

\section{Conflicts of interest}

The authors declare that they have no conflict of interest related to the publication of this manuscript.

\section{References}

ALVES, R.G. \& STRIXINO, G. 2000. Distribuição espacial de Oligochaeta em uma lagoa marginal do Rio Moji-Guaçu, Săo Paulo, Brasil. Iheringia, Sér. Zool.88:173-180.

ALVES, R.G., MARCHESE, M.R. \& MARTINS, R.T. 2008. Oligochaeta (Annelida, Clitellata) de ambientes lóticos do Parque Estadual Intervales (São Paulo, Brasil). Biota Neotro. 8(1):69-72. http://www.biotaneotropica. org.br/v8n1/pt/abstract?article+bn01708012008 (last access on 03/09/2018)

BEHREND, R.D., FERNANDES, S.E., FUJITA D.S. \& TAKEDA, A.M. 2009. Eight years of monitoring aquatic Oligochaeta from the Baía and Ivinhema Rivers. Braz. J.Biol., 69(2, Suppl.): 559-571.

BLETTLER, M., AMSLER, M., EZCURRA DE DRAGO, I \& MARCHESE, M. 2008. Effects of stream hydraulics and other environmental variables on density of Narapa bonettoi (Oligochaeta) in the Paraná River system. River. Res. Applic. 24: 1124-1140.

BRINKHURST, R.O. 1964. A taxonomie revision of the Alluroididae (Oligochaeta). P. Zool. Soc. Lond. 142:527-536.

BRINKHURST, R.O. \& JAMIESON, B.M.G. 1971. Aquatic Oligochaeta of the world. Edinburgh, Oliver and Boyd. 860p

BRINKHURST, R.O. \& MARCHESE, M.R. 1989. Guide to the freshwater aquatic Oligochaeta of South and Central America. Colección Climax 6. $179 \mathrm{pp}$.

BRINKHURST, R.O. \& MCKEY-FENDER, D. 1991. The anatomy of the pharynx of two predatory aquatic oligochaetes. Can. J. Zool. 69:669-675.

BURDON, F. J., MUNZ, N. A., REYES, M., FOCKS, A., JOSS, A., RÄSÄNEN, K., ALTERMATT, F., EGGEN, R. I.L. \& STAMM, C. 2019. Agriculture versus wastewater pollution as drivers of macroinvertebrate community structure in streams. Science of the Total Environment. 659: 1256-1265. Available: $<$ https://doi.org/10.1016/j.scitotenv.2018.12.372>.

CASTELLO, L. \& MACEDO, M. 2016. Large-scale degradation of Amazonian freshwater ecosystems. Glob. Change Biol. 22(3):990-1007.

COUCEIRO, S.R., HAMADA, N., FORSBERG, B.R. \& PADOVESI-FONSECA, C. 2009. Effects of anthropogenic silt on aquatic macroinvertebrates and abiotic variables in streams in the Brazilian Amazon. J. Soils Sediments. 10(1): 89-103.

DEDIEU, N., VIGOUROUX, R., CERDAN, P. \& CÉRÉGHINO, R. 2015. Invertebrate communities delineate hydro-ecoregions and respond to anthropogenic disturbance in East-Amazonian streams. Hydrobiologia, v. 742, n. 1, p. $95-105$.

DUMNICKA, E. 1994. Communities of Oligochaeta in mountain streams of Poland. Hydrobiologia. 278(1-3):107-110.

EZCURRA DE DRAGO, I., MARCHESE, M. \& MONTALTO, L. 2007. The Middle Paraná River: Limnology of a Subtropical Wetland (Springer). Cap 10: Benthic Invertebrates.251-275 pp.

FIDELIS, L. 2006. Estrutura da comunidade de insetos aquáticos em igarapés na Amazônia Central, com diferentes graus de preservação da cobertura vegetal e apresentação de chave de identificação para gêneros de larvas da ordem Odonata. Tese de Mestrado, Universidade Federal do Amazonas/ INPA, Manaus.

GOLTERMAN, H.L., SLY P.G. \& THOMAS R.L. 1983. Study of the relationship between water quality and sediment transport. Technical Papers in Hydrobiology, UNESCO.

HARMAN, W.J \& LODEN, M.S. 1978. Bratislavia unidentata (Oligochaeta: Naididae), a Re-Description. Southwest Nat. 23(4):541-544 
JAMES, S.W \& BROWN, G.G. 2006. Earthworm Ecology and Diversity in Brazil. In Soil Biodiversity in Amazonian and Other Brazilian Ecosystems (F.M.S Moreira \& J.O. Siqueira, eds). CABI Publishing, London, p. 56-116.

JUNK, W. J. 1983. As águas da região amazônica. In: SALATI, E., SHUBART, H.O.R., JUNK, W. \& KOWALEWSKI, M. 1914. Rodzaj Aulodrilus Bretscher 1899 i jego przedstawiciele. - The Genus Aulodrilus bretscher 1899 and its representatives. Anz. Akad. Wiss., Krakow. 54: 598-604.

LIMA, M.G. \& GASCON, C. 1999. The conservation value of linear forest remmants in central Amazonia. Biol. Conserv. 91(2):241-247.

LOPES A., D'ARC J.P., MARDEGAN S.F., HAMADA N. \& PIEDADE M.T.F. 2011. Influência do hábitat na estrutura da comunidade de macroinvertebrados aquáticos associados às raízes de Eichhornia crassipes na região do Lago Catalão, Amazonas, Brasil. Acta Amazon. 41(4):493-502.

MARCHESE, M.R. 2010. Ecología de Oligochaeta (Annelida) del río Paraná: Diversidad y Distribución. Tese de Doutorado. Universidad Nacional de Córdoba. Argentina.

MARTINS, R.T., STEPHAN, N.N.C. \& ALVES, R.G. 2008. Tubificidae (Annelida: Oligochaeta) as an indicator of water quality in an urban stream in southeast Brazil. Acta Limnol. Bras. 20(3):221-226

MORTATTI, A.F. 2004. Colonização por peixes no folhiço submerso: implicações das mudanças na cobertura florestal sobre a dinâmica da ictiofauna de igarapé de terra firme, na Amazônia Central. Tese de Mestrado, Instituto Nacional de Pesquisas da Amazônia/Universidade Federal do Amazonas, Manaus.

NESSIMIAN, J., DORVILLÉ, L., SANSEVERINO, A. \& BAPTISTA, D. 1998. Relation between floog pulse and functional composition of the macroinvertebrate benthic fauna in the lower Rio Negro, Amazonas, Brazil. Amazoniana, 35-50.

NESSIMIAN, J., VENTICINQUE, E.M., ZUANON, J., DE MARCO, P.JR., GORDO, M., FIDELIS, L., D’ARC, B.J., JUEN, L. 2008. Land use, habitat integrity, and aquatic insect assemblages in Central Amazonian streams. Hydrobiologia. 614(1):117-131.

NIJBOER, R.C., WETZEL, M.J. \& VERDONSCHOT, P.F.M. 2004. Diversity and distribution of Tubificidae, Naididae and Lumbriculidae (Annelida: Oligochaeta) in the Netherlands: an evaluation of twenty years of monitoring data. Hydrobiologia.520:127-141.

OMODEO, P. \& COATES, K.A. 2001. New alluroidids (Annelida, Clitellata) from Guyana. Hydrobiologia.463:39-47.

PARISH, J. 1981. Reproductive ecology of Naididae (Oligochaeta). Hydrobiologia. 83(1): 115-123.

PASSOS, M.I.S., NESSIMIAN, J.L. \& DORVILLÉ, L.F.M. 2003. Distribuição Espaço-temporal da Comunidade de Elmidae (Coleoptera) em um Rio na Floresta da Tijuca, Rio de Janeiro, RJ. Boletim do Museu Nacional. Nova Serie, Zoologia. 509:1-9.

PIGUET, E. 1906. Observations sur les Naïdidées et révision systématique de quelques espèces de cette famille. Rev. suisse de zool. 14: 185-315.

PINDER, A. 2010. Tools for identifying selected Australian aquatic oligochaetes (Clitellata: Annelida). Museum Victoria. Sci. Rep. 13: 1-26.

PRENDA, J.E. \& GALLARDO, A., 1992. The influence of environmental factors and microhabitat availability on the distribution of an aquatic oligochaete assemblage in Mediterranean River Basin. Int. Rev. gesamten Hydrobiol. 77(3):421-434.
REZENDE, R.F. 2007. Estrutura da comunidade de macroinvertebrados associados ao folhiço submerso de remanso e correnteza em igarapés da Amazônia Central. Biota Neotrop. 7(2):301-306. http://www.biotaneotropica. org.br/v7n2/pt/abstract?shortcommunication+bn01607022007 (last access on $03 / 09 / 2018$ )

RODRIGUES, L.F.T., LEITE, F.S. \& ALVES, R.G. 2013. Inventory and distribution of Oligochaeta (Annelida, Clitellata) in first-order streams in preserved areas of the state of Minas Gerais, Brazil. Biota Neotrop. 13(1):245-254. http://www.biotaneotropica.org.br/v13n1/en/abstract?inve ntory+bn02313012013 (last access on 03/09/2018)

RODRIGUEZ, P. \& REYNOLDSON, T.B. 2011. The Pollution Biology of Aquatic Oligochaetes (Springer), Dordrecht.

ROSA, BFJV, MARTINS, RT \& ALVES, RG. 2015. Distribution of oligochaetes in a stream in the Atlantic Forest in southeastern Brazil. Braz. J. Biol. vol. 75 , no. 1 , p. 1-7

SCHENKOVÁ, J. AND HELESIC, J. 2006. Habitat preferences of aquatic Oligochaeta (Annelida) in the "Rokytna" River, Czech Republic - a small highland stream. Hydrobiologia. 564:117-126

SIOLI, H. 1985. Amazônia. Fundamentos da ecologia da maior região de florestas tropicais. (Editora Vozes). Petropolis.

SYROVÁTKA, V., SCHENKOVÁ, J. \& BRABEC, K. 2009. The distribution of chironomid larvae and oligochaetes within a stony-bottomed river stretch: the role of substrate and hydraulic characteristics. Fundamental and Applied Limnology Archiv für. Hydrobiol. 174 (1):43-62.

TAKEDA, A. FUJITA, D.S, RAGONHA, F.H, PETSCH, D.K., MONTANHOLIMARTINS, M.C. 2017. Oligochaeta (Annelida) de ambientes aquáticos continentais do Estado do Mato Grosso do Sul (Brasil). Iheringia, Sér. Zool. 107(supl.): e2017107.

UNITED STATES. ENVIRONMENTAL PROTECTION AGENCY. 2004. Physical Stream Assessment: A Review of Selected Protocols for Use in the Clean Water Act Section 404 Program. p. 212

VERDONSCHOT, P.F.M. 1999. Micro-distribution of oligochaetes in a soft-bottomed lowland stream (Elsbeek; The Netherlands). Hydrobiologia.406:149-163

VERDONSCHOT, P.F.M. 2001. Hydrology and substrates - determinant of oligochaete distribution in lowland streams (The Netherlands). Hydrobiologia.463: 249-262

WALKER, I. 2004. Trophic interactions within the Utricularia habitat in the reservoir of the Balbina hydroelectric powerplant (Amazonas, Brazil). Acta Limnol. Bras. 16 (2):183-191

WAVRE, H. \& BRINKHURST, R.O. 1971. Interactions between some tubificid oligochaete and bactéria found in the sediments of Toronto Harbour, Ontario. J. Fish. Res. Board Can. 28:335-341.

RODRIGUEZ, P. \& REYNOLDSON, T.B. 2011. The Pollution Biology of Aquatic Oligochaetes. Springer, Dordrecht.

YAP, C. K., RAHIM ISMAIL, A., AZRINA, M.Z., ISMAIL, A. \& TAN, S.G. 2006. The Influential of Physicochemical Parameters on the Distributions of Oligochateas (Limnodrilus sp.) at the Polluted Downstream of the Tropical Langat River, Peninsular Malaysia. J. App. Sci. Environ. Manag. 10(3):135-140. 